\title{
Perception of Foreign Phonemes: The Case of Slovene Students of English
}

\begin{abstract}
The study focuses on assessing the state of foreign phoneme acquisition by foreign language (FL) students at the end of their undergraduate studies. To determine whether they prioritise vowels over consonants, a perception experiment was devised that focuses on the phonemes in Standard Slovene and General British reported as most problematic for Slovene learners of English. Thirty-three Slovene students of English were tested, along with a positive and a negative control group (CG). A set of stimuli was tested using the AX discrimination method; the participants listened to 60 phonemic contrasts, played in a pseudo-randomised order. The results foregrounded the most problematic phonemes which act as perceptual magnets. Analysis shows that the students can discriminate foreign phonemes well, and that they consistently perform better in discriminating vocalic contrasts.
\end{abstract}

Keywords: foreign language learning; phonological category; discrimination; perceptual magnet; vocalic prioritisation

\section{Percepcija tujih fonemov: primer slovenskih študentov angleščine}

\section{POVZETEK}

$S$ to raziskavo smo želeli oceniti, kako uspešno študenti tujih jezikov usvojijo tuje foneme do konca študija prve bolonjske stopnje. Da bi ugotovili, ali v procesu učenja tujega jezika dajejo prednost samoglasnikom pred soglasniki, smo zasnovali percepcijski eksperiment, ki se osredinja na foneme standardne slovenščine in angleščine, ki veljajo za najbolj težavne za Slovence, ki se učijo angleščine. Testirali smo 33 slovenskih študentov anglistike ter pozitivno in negativno kontrolno skupino. $\mathrm{V}$ eksperimentu smo uporabili metodo AX; udeleženci so poslušali 60 fonemskih kontrastov, predvajanih v psevdonaključnem vrstnem redu. $\mathrm{Z}$ analizo rezultatov smo izpostavili najbolj problematične foneme, ki se vedejo kot percepcijski magneti. Analiza je pokazala, da imajo študenti ob zaključku prve stopnje študija dobro sposobnost razločevanja tujih fonemov in da so se bolje odrezali pri razločevanju samoglasniških kontrastov.

Ključne besede: učenje tujih jezikov; fonemska kategorija; razločevanje; percepcijski magnet; prioritizacija samoglasnikov 


\section{Introduction}

Second/foreign language acquisition is a process in which a second language (L2) is acquired/learned in addition to the first language (L1). Some authors distinguish between the different contexts in which this occurs and choose their terminology accordingly - a second language may be described as 'acquired' when the acquisition occurs as part of everyday communicative situations, while a foreign language (FL) may be referred to as 'learned' when the learning happens through guided instruction in a classroom (Ellis 2015, 6). The term second language acquisition (SLA) is frequently used to cover both these contexts.

The role of L1 in the process of SLA has been a focus of numerous studies. Researchers now mostly believe that L1 language transfer, be it positive or negative, is "just one of several factors" in L2 acquisition, and that "learners follow a similar order and sequence of acquisition irrespective of their first language" (Ellis 2015, 11). When it comes to FL sounds, language transfer is most noticeable on the level of production L2 speakers often have easily detectable and recognisable accents. Studies have shown that explicit instruction of pronunciation can be beneficial, so teachers should work on it by considering a variety of factors, the L1 background of their students being one of them (Saito 2012; Saito and Lyster 2012).

The difficulties observed in learners' production are often described as being closely linked to perception (Watkins, Strafella, and Paus 2003). The first studies looking at perception of FL sounds can be dated to the beginning of the 1970s, with prominent papers by authors such as Abramson and Lisker (1970) and Stevens et al. (1969). These studies investigate the ability to discriminate between similar FL sounds - an ability which has been described as almost non-existent for people unfamiliar with the FL in question (Escudero 2009). Most researchers in the field agree that it is possible to acquire the ability to discriminate these contrasts (Escudero 2002), and their studies aim to identify the factors affecting these processes, such as the listener's age and native language (Bohn 1995).

While the context of acquisition has been thoroughly explored, the intrinsic difficulty of certain phonemic contrasts in relation to others in SLA remains largely uncharted territory. In this context, the distinction between consonants and vowels becomes especially relevant. Thus, the main aim of the experimental study presented here is to identify General British (GB) phonemes that are problematic for speakers of Slovene, and to determine if the acquisition rate of FL consonantal contrasts is different to the one measured for FL vocalic contrasts. The results of the study can be used to determine the causes of perception difficulties, and to provide suitable feedback to students and language teachers alike. The paper presents an overview of the relevant literature (Sections 1 and 2), the methodology and research questions (Section 3), the 
results of the experiment (Section 4), a discussion of the results (Section 5) and the conclusion (Sections 6).

\section{Literature Overview}

\subsection{Perception of Phonemes}

Speech perception always involves cognitive processing of the incoming sound wave. The listener analyses its properties before assigning it a symbolic representation used in the subsequent linguistic processing. Tatham and Morton (2011,152-68) explain that according to some theories the acoustic information is analysed on the level of sound segments and the parameters that define them. The consequent categorisation of phonemes differs from language to language, which means that certain categories may coincide, while others differ significantly.

Vowels possess comparatively simple acoustic structures, which makes their recognition relatively easy. They have a near-periodic waveform and can mostly be distinguished from one another by analysing two of their formants, F1 and F2 (Carlson, Fant and Granstrom 1970, 1975), and their transitions (Lindblom and Studdert-Kennedy 1967). They can be described with a small set of phonetic features, being restricted to the dorsal place of articulation. The distinction is made according to where (front, back) and by how much (high, low) the tongue is raised, and the shape of the lips (rounded, spread). Consonants, on the other hand, are aperiodic and have a quasichaotic waveform, making it difficult to determine their boundaries. They exhibit a wider spectrum of possible places of articulation, and, correspondingly, a wider array of possible phonetic features.

Since utterances of sounds in natural speech seldom occur in a vacuum, a transition over the phoneme boundaries can result in an audible effect on an adjacent vowel, affecting its length and sometimes even quality (e.g. nasality). As some consonants tend to be very briefly articulated, the cues for their discrimination are held in the adjacent vowel (Cruttenden 2014, 21-22). For example, the length of the preceding vowel can aid in the discrimination between $/ \mathrm{t} /$ and $/ \mathrm{d} /$ in words such as 'foot' and 'food' when the two plosives are inaudibly released in the word-final position.

In the process of learning English as L1, vowels are generally mastered by the age of 3 , whereas fricatives, for example, are challenging for some children until the age of 5 or 6 , especially due to the five possible places of articulation which require "delicate adjustments" of the tongue (Cruttenden 2014, 6, 195). At first, the fricatives in initial positions are generally replaced by the nearest plosives (e.g. $/ \mathrm{f} />/ \mathrm{p} /$ ), and only after the voiceless fricatives are successfully acquired, can the voiced ones be expected to appear (Cruttenden 2014, 195-6). 
Research has shown that across all relevant ages vowels contribute more to the intelligibility and comprehensibility of sentences than consonants. The study on normal-hearing and hearing-impaired listeners by Kewley-Port, Burkle and Lee (2007) suggests that vowels are also more easily recognised in poor listening conditions due to their lower frequency and stronger intensity of articulation. The finding may indicate that FL learners should prioritise new (unfamiliar) vowels over consonants, as this would likely lead to their faster proficiency in the new language.

In the process of second language acquisition, learners create categories in which related data are combined into larger units with their own internal structures. Such a categorisation of sounds starts at an early age - babies are able to successfully discriminate more sounds than there are in their L1. But even in the first year of their lives, they lose some of this ability, especially when it comes to sounds to which they are not exposed regularly, i.e., the sounds outside the repertoire of their L1 (Werker et al. as quoted in Kuhl 1991, 104). By this time, each L1 sound starts to form an individual phonetic category, and phonologically related phonetic categories (allophones) start forming phonological categories. Jurančič $(2014,48)$ observes that the fact that children establish their phonological inventory so early and that this development is greatly influenced by their L1 can "provide a basis on which to predict which features are potential sources of L1 interference in second or foreign language learning".

Each category has a range of what we still consider to be the same sound; hence, phonologically different segments can be assigned the same categories. According to Kuhl $(1991,93)$, there exist prototypes or "best versions" of each sound. They are recognised faster and remembered at a better rate. A prototype is the basis of a category, and as such acts as a 'perceptual magnet'. Kuhl $(1991,99)$ explains that the "[s] urrounding members of the category are perceptually assimilated to it to a greater degree than would be expected on the basis of real psychophysical distance. [...] The perceptual space appears to be 'warped', effectively shrunk around the prototype."

As can be expected, the compacting of categories observed in L1 affects the perception of L2. Best (1995) proposes that the assimilation of new phonemes occurs in various ways. A pair of L2 segments can be assimilated to different L1 categories, to the same L1 category or outside any particular L1 category. Flege asserts that the more different an L2 sound is from an L1 sound, the more likely it is that it will be successfully discerned (Flege 1995, 240), and that "the greater the perceived difference of an L2 sound from the closest L1 sound, the more likely that a separate category will be established for the L2 sound" (Flege 1995, 264).

The L1 sound system shapes our perception of other languages, functioning as a sieve to filter the cues which are phonologically relevant in our L1 (Trubetzkoy as cited in 
Flege 1995, 237). Thus, a sound that is a phoneme in L2, but only an allophone in $\mathrm{L} 1$, is likely to be assimilated into the L1 phonological category. However, phonetic (and, by extension, phonological) categories are not set in stone and can be somewhat moulded with sufficient practice:

The phonetic systems used in the production and perception of vowels and consonants remain adaptive over the life span, and [...] reorganise in response to sounds encountered in an L2 through the addition of new phonetic categories, or through the modification of old ones. (Flege 1995, 233)

When an L2 phoneme (or position-sensitive allophone) is successfully acquired, it forms a new phonological category which is no longer related to the existing L1 phoneme (Flege 1995, 263). Flege's observations also led him to the conclusion that although we possess the motoric abilities to pronounce foreign sounds, we fail to produce them accurately due to insufficient perception input $(1995,236)$.

Flege's and other studies (see Flege 1988 1992a, 1992b, 1995; Rochet 1995) have shown that the cause of mispronunciation responsible for foreign accents is of a perceptive nature. The reasons include inaccurate perception of L2 sounds, inadequate phonetic input, insufficient motivation, a wish to retain a foreign accent and incorrect habits established in the early stages of L2 learning.

\subsection{Sound Systems}

In Sections 2.2.1 and 2.2.2 the Standard Slovene (StS) and the General British (GB) sound systems are presented and compared. The discussion is mostly limited to the phonemes that have been previously identified as problematic for Slovene speakers (Collins, Šuštaršič, and Komar 2014; Šuštaršič 2005; Komar 2017; Stopar 2015, 2017, 2019); they represent the focus of the present study.

One of the more notable differences between StS and GB is in the number of phonemes. While the number of consonants is similar ( 24 and 21 , respectively), StS has a much smaller vowel system than GB (8 and 21, respectively), which often leads to neutralisation of GB vowels (Šuštaršič 2005, 9). As Šuštaršič points out $(2005,5-6)$, problems for Slovene speakers mainly occur with the front GB vowels /e/ and /æ/.

The consonants that have been identified as problematic for Slovene speakers involve the type of articulation that can be described as a marker of a foreign accent (Collins, Šuštaršič and Komar 2014). Šuštaršič $(2005,24)$ categorises them in three groups: 1) the equivalent consonantal phonemes that do not present problems for FL learners, as they are already found in $L 1 ; 2)$ the partially equivalent consonantal phonemes that differ either in place $(/ \mathrm{t}, \mathrm{d}, \mathrm{h} /)$ or in manner $(/ \mathrm{I} /)$ of articulation, which makes them more difficult to acquire; and 3) the non-equivalent consonantal phonemes 
that exist in $\mathrm{L} 1$ only as allophones $(/ \mathrm{y}, \mathrm{w} /)$ or do not exist in $\mathrm{L} 1$ at all $(/ \theta, \partial /)$, which makes them the most challenging for Slovene speakers.

\subsubsection{Standard Slovene}

The relatively small set of $\mathrm{St} S$ vowels $(8)^{1}$ is presented in Figure 1 (cf. Šuštaršič, Komar and Petek 1999, 137).

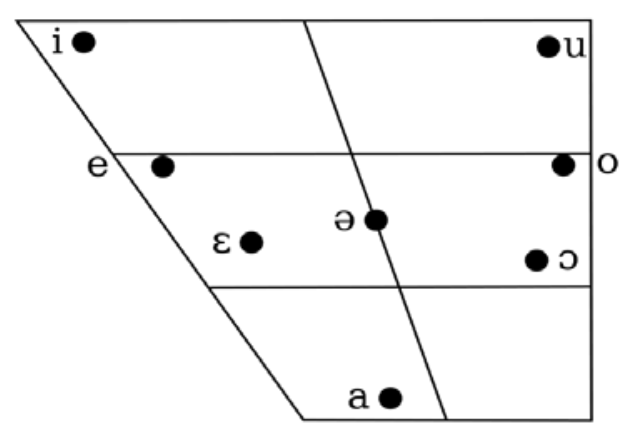

Figure 1. StS vowels.

Of the eight vowels depicted in the above vowel quadrilateral, two, /e/ and $/ \varepsilon /$, are studied in this paper.

- /e/: Toporišič (2000, 47-49) describes /e/ as an unrounded close-mid front vowel. The tongue is pressed forward and raised somewhat lower than for $/ \mathrm{i} /$, the high point is approximately in line with the upper teeth. The rims of the tongue slightly touch the upper molars. The lips are spread. It corresponds to C2. Šštaršič $(2005,10)$ states that $\mathrm{StS} / \mathrm{e} /$ is very close compared to the nearby GB vowels. ${ }^{2}$ Most Slovene speakers correctly identify it as too close to replace the GB /e/.

- /ع/: In line with Toporišič (2000), / $/ \varepsilon /$ is an unrounded open-mid front vowel. The tongue is pressed forward and raised slightly above the lower teeth. The rims of the tongue barely touch the upper molars. The lips are spread. It is somewhat above $\mathrm{C} 3$ and slightly more centralised. $\mathrm{St} S / \boldsymbol{\varepsilon} /$ is identified by most Slovene speakers as closest to GB /e/ and /æ/, which is why it tends to be neutralised in production and perception (Šuštaršič 2005, 10; Collins, Šuštaršič, and Komar 2014, 53; Stopar 2015, 89; 2019).

It should be noted that the $S t S$ vowel system distinguishes two phonological systems: the non-tonemic, based on stress and vowel-length, and the tonemic, based on stress, vowel length and pitch (Toporišič 2000, 63-64). In this paper, the issue of pitch is not addressed as the speaker involved in the experiment was instructed to produce each stimulus with the same, falling pitch.

2 In some contexts (e.g. before $/ \mathrm{f} /$ ) and especially in dialects of certain regions (e.g. Upper Carniola, Central Slovenia), it is pronounced even more close, so that it may at times be identified as $/ \mathrm{I} /$ by speakers from other regions, cf. Tivadar (2004). 
The set of StS consonants comprises 21 phonemes. This study focuses on the following consonants (cf. Šuštaršič, Komar, and Petek 1999, 135-36; Toporišič 2000, 73-82).

- /d/ is a voiced dental plosive; it differs from $\mathrm{GB} / \mathrm{d} /$ in the place of articulation (dental in StS and alveolar in GB). When compared to GB /ð/, Šuštaršič $(2005,26,29)$ observes that it has a different manner of articulation, but is nevertheless often used as a substitute for GB /ð/ even by advanced Slovene speakers of English.

- $/ \mathbf{t} /$ is a voiceless dental plosive; it differs from $\mathrm{GB} / \mathrm{t} /$ in the place of articulation (StS dental and GB alveolar). StS / $/$ / is frequently used as a substitute for GB / / / (Šuštaršič 2005, 26, 29); the two phonemes differ in the manner of articulation.

- /f/ is a voiceless labiodental fricative. Although the phoneme /f/ has the same VPM labels in StS and GB, we include it here because Slovene speakers sometimes use it as a substitute for GB / $\theta /$ (the two sounds differ only in the place of articulation).

- /x/ is a voiceless velar fricative; it differs from $\mathrm{GB} / \mathrm{h} /$ in the place of articulation (velar and glottal).

- /f/ is a (voiced) alveolar tap, which differs from the GB approximant / $\mathbf{d} /$ in the manner of articulation.

\subsubsection{General British}

The inventory of GB phonemes lists 21 vowels (14 monophthongs and seven diphthongs) and 24 consonants. Their descriptions in this section are summarised from Cruttenden (2014, 96-237).

GB vowels are divided into monophthongs and diphthongs; this study focuses on the former only, namely on the KIT-vowel /I/, the DRESS-vowel /e/, the SQUARE-vowel / $\varepsilon$ :/, and the TRAP-vowel $/ \mathfrak{x} /$. It is noteworthy that the list includes the SQUARE-vowel $/ \varepsilon: /$, which had been described as a diphthong /ea/ until the last, 8th edition of Gimson's Pronunciation of English. The current edition establishes / $\varepsilon$ :/ as the GB standard and considers the diphthong/ea/ to be a marked pronunciation (Cruttenden 2014, 78, 84).

GB has a rich vowel system - crowding in the vowel chart is most noticeable on the front axis. The presented phonemes are limited to the range from just above $\mathrm{C} 2$ to $\mathrm{C} 4$ in order to keep the quantity of data manageable and the experiment practical. The vowel chart below follows Wells (2008, xxxiii-xxiv) but is adapted to include the latest changes discussed above, namely / $\varepsilon: /$ and $/ a /$. 


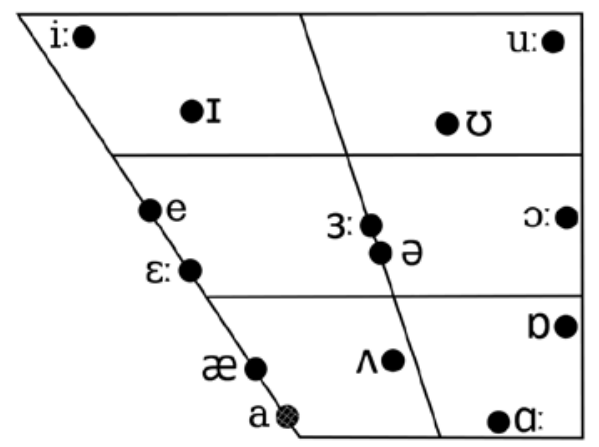

Figure 2. GB vowels.

- /I/ is an unrounded near-close near-front vowel. The part of the tongue nearer to the centre is pressed slightly forward and raised just above the closemid position. The side rims make slight contact with the upper molars. The lips are loosely spread. It is closest to C2, but more centralised. Compared to $\mathrm{StS} / \mathrm{e} /$, it is more centralised (Collins, Šuštaršič, and Komar 2014, 47). Because Slovene does not have an intermittent vowel between $\mathrm{StS} / \mathrm{i} / \mathrm{and}$ $\mathrm{StS} / \mathrm{e} /, \mathrm{GB} / \mathrm{I} / \mathrm{can}$ be problematic for Slovene FL learners. The results of a contrastive analysis by Šuštaršič $(2005,12)$ show that the degree of opening is approximately the same as for $\mathrm{StS} / \mathrm{e} /$.

- /e/ is an unrounded mid front vowel. The front of the tongue is pressed forward and approximately in line with the lower teeth. The side rims make slight contact with the upper molars. The lips are loosely spread. It falls between C2 and C3, a bit closer to the latter. /e/ may present difficulties for learners if L1 has phonemes that correspond to C2 and C3 (Cruttenden 2014). Šuštariššcs contrastive analysis also shows the great proximity of GB /e/ and StS / $/ \varepsilon /$ (Šuštaršič 2005, 12). GB /e/ is often produced too open, and so replaced by StS /ع/ (Collins, Šuštaršič, and Komar 2014, 116).

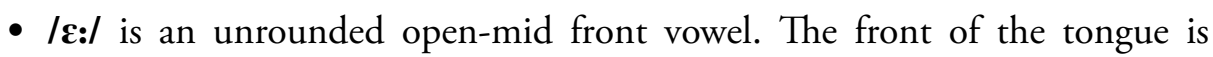
pressed forward and dropped somewhat below the lower teeth. The side rims make no contact with the upper molars. The lips are neutrally spread. It is most similar to C3.

- $/ \mathfrak{x} /$ is an unrounded open-mid to near-open front vowel. The mouth is more open than for $/ \varepsilon: /$. The tongue is raised between the open-mid and fully open positions. The side rims make slight contact with the back upper molars. The lips are neutrally open. It is most similar to C3. This phoneme has dropped recently to a position closer to $\mathrm{C} 4$, which is shown by the placement of /a/. The higher of the two positions explains the confusion with Slovene $/ \varepsilon /$ : in line with Šuštaršič $(2005,71), / \Re /$ is often pronounced too close. 
With regard to the GB consonants, the study focuses on seven phonemes that have been reported as problematic in the literature (Šuštaršič 2005; Collins, Šuštaršič, and Komar 2014). They are as follows:

- /t/ is a voiceless alveolar plosive;

- /d/ is a voiced alveolar plosive;

- /f/ is a voiceless labiodental fricative; in some regional English accents (e.g. Cockney), it replaces the voiceless dental fricative $/ \theta /$;

- $/ \boldsymbol{\theta} /$ is a voiceless dental fricative;

- /ð/ is a voiced dental fricative;

- $/ \mathbf{h} /$ is a voiceless glottal fricative;

- / $\mathbf{x} /$ is a (voiced) alveolar approximant.

\section{Methodology}

The main goal of the experimental study was to assess the state of accurate discrimination of non-native phonemes in Slovene students at the end of their third year at the Department of English in Ljubljana. We hypothesised that the students would be better at discriminating vocalic contrasts rather than consonantal ones, as according to some linguistic theories vowels contribute more to the understanding of speech and carry more information on the surrounding sounds (Kewley-Port, Burkle, and Lee 2007; Cruttenden 2014). To confirm this, an experiment was designed that examined and compared the performance of Slovene third-year students of English. ${ }^{3}$

\subsection{Participants}

The participants were third-year BA or first-year MA students at the Faculty of Arts, University of Ljubljana, in the academic year 2016-17. They were invited to participate in the experiment a week prior to the experiment, and the volunteers were assigned individual time slots. The student participants formed the focus group.

To accurately place the results of the focus group in the range of ability to discriminate non-native phonemes, positive and negative control groups (hereafter CG) were also formed: one comprising advanced/native speakers and the other consisting of beginners. Since it proved impossible to find a group of participants with little to no exposure to English, the negative CG included participants who do not use English in their daily lives, never or seldom listen to English music, and who claim that they have great difficulties in speaking and understanding the language. The negative CG allowed us to assess whether the experiment is too easy. The positive CG included participants who are in contact with English daily. Their results were used to evaluate the phonemic quality of the recorded stimuli, i.e. whether the recordings sound genuine to a native speaker's ear.

The experiment was part of S. Jošt's MA project (2018, supervised by A. Stopar and M. Šekli), which evolved from a previous experiment conducted by S. Jošt and D. Krassnig at the University of Konstanz (2015, supervised by M. Pohl). 
TABLE 1. Participants in the focus and control groups.

\begin{tabular}{|l|l|l|l|}
\hline & Focus group & Positive CG & Negative CG \\
\hline $\begin{array}{l}\text { Total no. of } \\
\text { participants }\end{array}$ & 33 & 5 & 5 \\
\hline Sex & 22 female, 10 male & 2 female, 3 male & 3 female, 2 male \\
\hline $\begin{array}{l}\text { Semester of } \\
\text { study }\end{array}$ & $\begin{array}{l}\text { 6th (22 part.), } \\
8 \text { th (11 part.) }\end{array}$ & NA & NA \\
\hline $\begin{array}{l}\text { Age of } \\
\text { participants }\end{array}$ & $21-28$, avg. 23 & $26-32$, avg. 29 & $18-24$, avg. 22 \\
\hline $\begin{array}{l}\text { Native } \\
\text { language }\end{array}$ & Slovene & Slovene & Slovene \\
\hline $\begin{array}{l}\text { Regular } \\
\text { contact with } \\
\text { English }\end{array}$ & $81 \%$ & $100 \%$ & $40 \%$ \\
\hline Type of contact & $\begin{array}{l}\text { travel to English- } \\
\text { speaking countries, } \\
\text { media, books, audio } \\
\text { books, work (tourism, } \\
\text { translating, tutoring, } \\
\text { teaching English), } \\
\text { native-speaker friends }\end{array}$ & $\begin{array}{l}\text { native-speaker } \\
\text { friends, work } \\
\text { (teaching English, } \\
\text { interpreting...), } \\
\text { media, study or work } \\
\text { in England }\end{array}$ & music, travel \\
\hline
\end{tabular}

\subsection{Speaker and Recording Procedure}

The stimuli were recorded by a female native speaker of Slovene with professional training in English phonetics and with experience teaching this subject at the Faculty of Arts, University of Ljubljana. A bilingual native speaker of Slovene and English was not available during the preparation of the experiment; however, the speaker's pronunciation is at the level of a native speaker. The speaker also has experience with public speaking on radio, which simplified the recording procedure.

The speaker was given a list of monosyllabic words, grouped by categories and divided by languages, and asked to produce all items with the same pitch. The words were written in phonemic transcription. The speaker recorded a string of words for each phoneme separately, so that the quality of the tested phoneme (or category) remained the same. The string recordings were later cut into individual recordings (one for each word) with the program Audacity.

The digital voice recorder SONY ICD-SX1000 was used to record the stimuli. The recordings were processed in Audacity: noise reduction was applied, the pitch was equalised, and the recordings were also amplified to increase the volume of the audio.

\subsection{Stimuli}

The choice of stimuli was based on the 11 GB phonemes that were identified as 
absent from $\mathrm{StS}$, and their possible substitutes in $\mathrm{St} \mathrm{S}$ (see the discussion in 2.2). They were categorised as shown in Table 2.

TABLE 2. Categorisation of stimuli. ${ }^{4}$

\begin{tabular}{|l|l|c|l|}
\hline Label & Description & Label & Description \\
\hline S1 & GB vowel DRESS & S6 & StS vowel DEBLO \\
\hline S2 & GB vowel TRAP & S7 & $\begin{array}{l}\text { GB voiceless consonant with a different } \\
\text { place of articulation }\end{array}$ \\
\hline S3 & GB vowel sQUARE & S8 & $\begin{array}{l}\text { GB voiced consonant with a different place } \\
\text { of articulation }\end{array}$ \\
\hline S4 & GB vowel KIT & S9 & $\begin{array}{l}\text { StS voiceless consonant with a different } \\
\text { place of articulation }\end{array}$ \\
\hline S5 & StS vowel LES & S10 & $\begin{array}{l}\text { StS voiced consonant with a different place } \\
\text { of articulation }\end{array}$ \\
\hline
\end{tabular}

The aim of the experiment was to determine whether the participants are able to discriminate between two similar FL phonemes (GB-GB), and a combination of an L1 phoneme and a similar FL phoneme (StS-GB). Table 3 presents the contrasts observed in the experiment.

TABLE 3. Categorisation of contrasts.

\begin{tabular}{|c|c|c|c|c|}
\hline Code & Label & Relation & Categories & Contrast \\
\hline 1 & DRESS VS. TRAP & GB-GB & S1-S2 & $|\mathrm{e} /-| \mathfrak{x} \mid$ \\
\hline 2 & DRESS vs. SQUARE & GB-GB & S1-S3 & /e/-/ع:/ \\
\hline 3 & TRAP VS. SQUARE & GB-GB & S2-S3 & $|æ /-/ \varepsilon:|$ \\
\hline 4 & DRESS VS. DEBLO & GB-StS & S1-S6 & $|\mathrm{e} /-| \varepsilon \mid$ \\
\hline 5 & TRAP VS. DEBLO & GB-StS & S2-S6 & $|x /-| \varepsilon \mid$ \\
\hline 6 & SQUARE VS. DEBLO & GB-StS & S3-S6 & $\mid \varepsilon: /-/ \varepsilon /$ \\
\hline 7 & DRESS VS. LES & $\mathrm{GB}-\mathrm{StS}$ & S1-S5 & le/-lé/ $/ 5$ \\
\hline 8 & KIT VS. LES & GB-StS & S4-S5 & /I/-lél \\
\hline 9 & $\begin{array}{l}\text { Place of } \\
\text { articulation }\end{array}$ & GB-StS & S7-S9, S8-S10 & $\begin{array}{l}/ \theta /-/ \mathrm{t} / ; / \theta /-/ \mathrm{f} / ; / \mathrm{h} /-/ \mathrm{x} / ; \\
/ \mathrm{x} /-/ \mathrm{r} / ; / \partial /-/ \mathrm{d} /\end{array}$ \\
\hline 10 & Voicing & $\begin{array}{l}\text { GB-GB; } \\
\text { StS-StS }\end{array}$ & S7-S8; S9-S10 & $/ \theta /-/ \partial / ; / \mathrm{t} /-/ \mathrm{d} /$ \\
\hline 11 & Control & $\begin{array}{l}\text { identical } \\
\text { items }\end{array}$ & SX-SX & \\
\hline
\end{tabular}

When possible, we opted for nonsensical monosyllables, which follow the same pattern (e.g. / $/$ av/-/ðaひ/).

4 For GB vowels, the lexical sets created by Wells (1982) were used. In this system each vowel is represented by a prototypical monosyllabic word. Parallel lexical sets were created for StS: les 'wood' for StS /e/ and deblo 'tree trunk' for $\mathrm{StS} / \varepsilon /$.

5 For $\mathrm{StS} / \mathrm{e} /$ the notation with the acute accent is used henceforth /é/ to distinguish it from the GB /e/. 


\subsubsection{Vowels}

The tested vowels appeared between two consonants $(\mathrm{C}-\mathrm{V}-\mathrm{C})$. The initial phoneme varied to test the vocalic phoneme in different environments and to avoid the influence of the initial phoneme. The final phoneme was the voiceless plosive $/ \mathrm{t} /$, as it naturally appears in this context quite often in both tested languages. Voiced consonants would be unsuitable, as in word-final position in English they are devoiced (but lenis), while in Slovene they revert to their voiceless (but fortis) pairs.

Since the crowding of vocalic phonemes is most noticeable on the front axis of the vowel quadrilateral, the experiment focused on four GB monophthongs that range from just above $\mathrm{C} 2$ to $\mathrm{C} 4$ and two $\mathrm{StS}$ monophthongs in the same vowel space. Table 4 presents the relevant stimulus words.

TABLE 4. List of monosyllabic words with vocalic phonemes.

\begin{tabular}{|c|c|c|c|c|c|c|}
\hline GB DRESS /e/ & /let/ & /jet/ & /bet/ & /pet/ & $/ \operatorname{det} /$ & $/ \mathrm{fet} /$ \\
\hline GB TRAP /æ/ & /læt/ & /jæt/ & /bæt/ & /pæt/ & $/ \mathrm{d} æ \mathrm{t} /$ & $/ f_{\mathfrak{~}} /$ \\
\hline GB SQUARE / $\varepsilon: /$ & $/ \mathrm{l}_{\mathrm{a}: \mathrm{t}} /$ & /je:t/ & /be:t/ & /pe:t/ & $/ \mathrm{d} \varepsilon: \mathrm{t} /$ & /ff:t/ \\
\hline GB KIT /I/ & /lit/ & /jit/ & /bit/ & $/$ pit/ & $/ \mathrm{d} i \mathrm{t} /$ & $/ \mathrm{fit} /$ \\
\hline StS LES /él & /lét/ & /jét/ & /bét/ & /pét/ & /dét/ & /fét/ \\
\hline$S_{\text {TS }}$ deblo $/ \varepsilon /$ & $/$ let/ & /jet/ & $/ \mathrm{bct} /$ & $/ \mathrm{p} \varepsilon \mathrm{t} /$ & $/ \mathrm{d} \varepsilon \mathrm{t} /$ & $/ f \varepsilon t /$ \\
\hline
\end{tabular}

\subsubsection{Consonants}

The tested consonantal phonemes appeared in the word-initial position. In the GB set, they were followed by the diphthong /ao/, which is a relaxed open sound and fairly close to the Slovene [au]. ${ }^{6}$ Both are common in word-final position in English (e.g. in now) and in Slovene (e.g. in dal 'gave' and rokav 'sleeve').

As for the place of articulation of / $t /$ and / $/$ /, we propose that very few, if any, Slovene students of English make the distinction between the dental (StS) and alveolar (GB) articulations (see 2.2.1), except perhaps in the word-initial position where $\mathrm{GB} / \mathrm{t} /$ is aspirated (not a phonologically distinctive feature). Thus, a single set of recordings represented both $/ \mathrm{t} /$ and $/ \mathrm{d} /$. It should also be noted here that the focus of the experiment was on $/ \theta /$ and $/ \partial /$, the pair of phonemes from the third category of difficulty (Šuštaršič 2005, 24).

TABLE 5. List of English and Slovene monosyllabic words with tested consonantal phonemes.

\begin{tabular}{|l|l|l|l|}
\hline GB unvoiced consonant & $/ \mathrm{hav} /$ & $/ \theta \mathrm{av} /$ & \\
\hline StS unvoiced consonant & $/ \mathrm{xav} /$ & $/ \mathrm{tav} /$ & $/ \mathrm{fav} /$ \\
\hline
\end{tabular}

\footnotetext{
StS does not have diphthongs but categorises such combinations as two phonemes (vowel $+/ \mathrm{j} /$ or $[\mathrm{u}]-\mathrm{a}$ bilabial allophone of the approximant /o/). Nevertheless, /að/ can safely be used as a substitute for [au] (Šuštaršič 2005, 10), and vice versa.
} 


\begin{tabular}{|l|l|l|l|}
\hline GB voiced consonant & $/$ ðao/ & $/ \mathrm{Ja} /$ & \\
\hline StS voiced consonant & $/ \mathrm{da \sigma} /$ & $/ \mathrm{ra \sigma} /$ & \\
\hline
\end{tabular}

\subsection{Procedure}

The participants listened to pairs of monosyllabic recordings which differed in one phoneme (hereinafter IDs) and identified them as the same or different. The AX method was employed for the experiment; the program ZEP (Veenker 2013) was used for the testing procedure.

The testing was divided into two phases: the preliminary phase with feedback, followed by the main testing phase without feedback. The preliminary phase was comprised of four IDs, and the main phase of 60 IDs. All IDs were played in a pseudo-randomised order. The interstimulus interval for all trials was $500 \mathrm{~ms}$. After hearing the recordings, the participants had to respond in an interval of $2000 \mathrm{~ms}$. The responses were identified as "correct" (1) or "incorrect" (0). If they failed to answer before the next ID was played, the response was identified as "unanswered" $(-1)$. A counter tracking the progress of the experiment was placed at the bottom of the screen.

The experiment was conducted in May 2017 over a period of 14 days. Each participant was tested individually in a controlled environment. First, the participants were asked to fill in a short, anonymous questionnaire. Before the preliminary phase, they were given instructions in Slovene. The instructions were also given in written form before the beginning of the experiment.

The participants were then given a set of headphones and a computer mouse, and asked to complete the preliminary phase with the experiment supervisor in the room to ensure that all the conditions for successful execution of the experiment were met. The preliminary phase consisted of four IDs with feedback. After the participant completed the four sets, the supervisor answered any questions that arose and checked that all instructions were clear and the volume was comfortable. Then the supervisor left the room and the participants listened to 60 IDs without feedback.

\subsection{Data Processing}

The results for each participant were automatically saved as a .cvs file at the end of each trial. The answers were identified as "correct" (1), "incorrect" (0), or "unanswered" (-1); any unanswered item (due to time-out) was considered to have been answered incorrectly with a response time (hereinafter RT) of $2000 \mathrm{~ms}$.

The results were categorised by group (focus group, positive CG, negative CG), by tested parameters (accuracy and response time), and by phonological categories (GB vs. StS/GB contrasted vowels, place of articulation, voicing, control). 
The statistical analysis was conducted using the various functions of Microsoft Excel 2016. We calculated the total number of correct responses by all participants per ID (in numbers and percentages) to determine the easiest and most difficult phonemes. Then we applied the same method to the RT data (the average RT by all participants per ID, and the total average RT of all IDs). Next, we took the percentage of accurate discriminations by all participants per ID, and divided it by the average RT by all participants per ID. Moving average trendlines were included in all charts to investigate if the patterns align. Based on the RT trendline, four patterns were discerned with regard to perceived and actual difficulty of phonemic contrasts (also see Table 6 below):

- Pattern I: high accuracy and short RT;

- Pattern II: high accuracy and long RT;

- Pattern III: low accuracy and long RT;

- Pattern IV: low accuracy and short RT.

High/low accuracy was defined as the number of correct discriminations above/below average, respectively. Short/long RT was defined as the average RT per ID below/ above the total average RT, respectively. All IDs were categorised in the correlation patterns according to these criteria.

Also, the average RT and the total number and percentage of accuracy per phonological category were calculated. To compare the results and prove the validity of both methods, phonological categories and correlation patterns were cross-referenced with the accuracy identified for the observed phonological categories.

Finally, three supercategories were established and studied: vowels $(V)$, consonants $(C)$ and control (CC). The average RT and the percentage of accuracy per supercategory were calculated, and the supercategories were cross-referenced with correlation patterns (expressed in percentages).

The data in the following sections is presented in the form of charts; for detailed results, see Appendices I and II.

\section{Results}

\subsection{Focus Group}

Figures 3, 4 and 5 show the percentage of correct discriminations, the average RT, and the relationship between the two.

The percentage of accuracy is presented in Figure 3..$^{7}$ Out of 44 differing IDs, nine were answered correctly $100 \%$ of the time, which accounts for $20 \%$. IDs 3 and 7

The data per ID are available in Appendix I. This includes the total sum and the percentage of correct discriminations per ID, as well as the average RT per ID. Furthermore, it shows the total average of correct discriminations, the total percentage of accuracy, and the total average RT. 

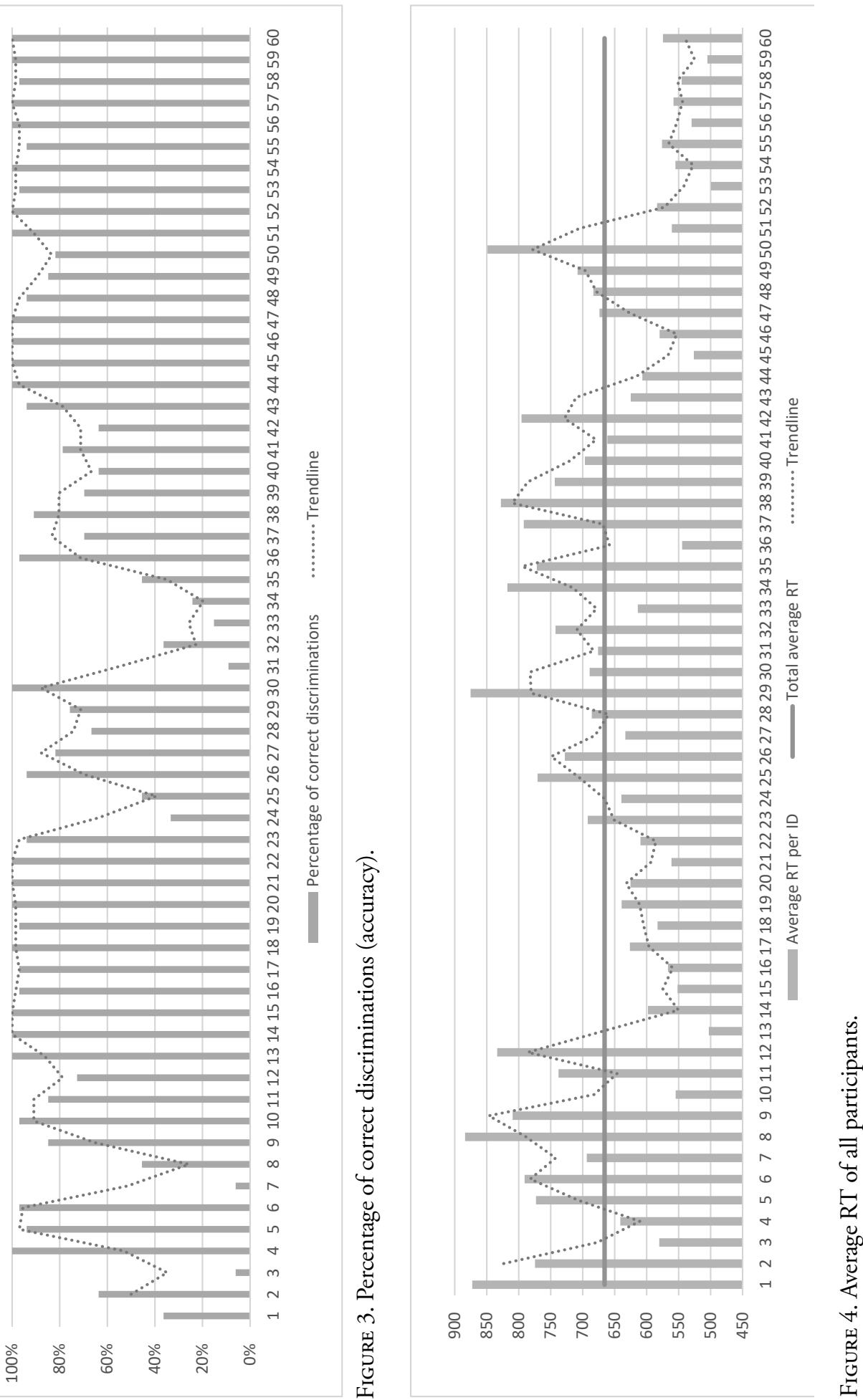


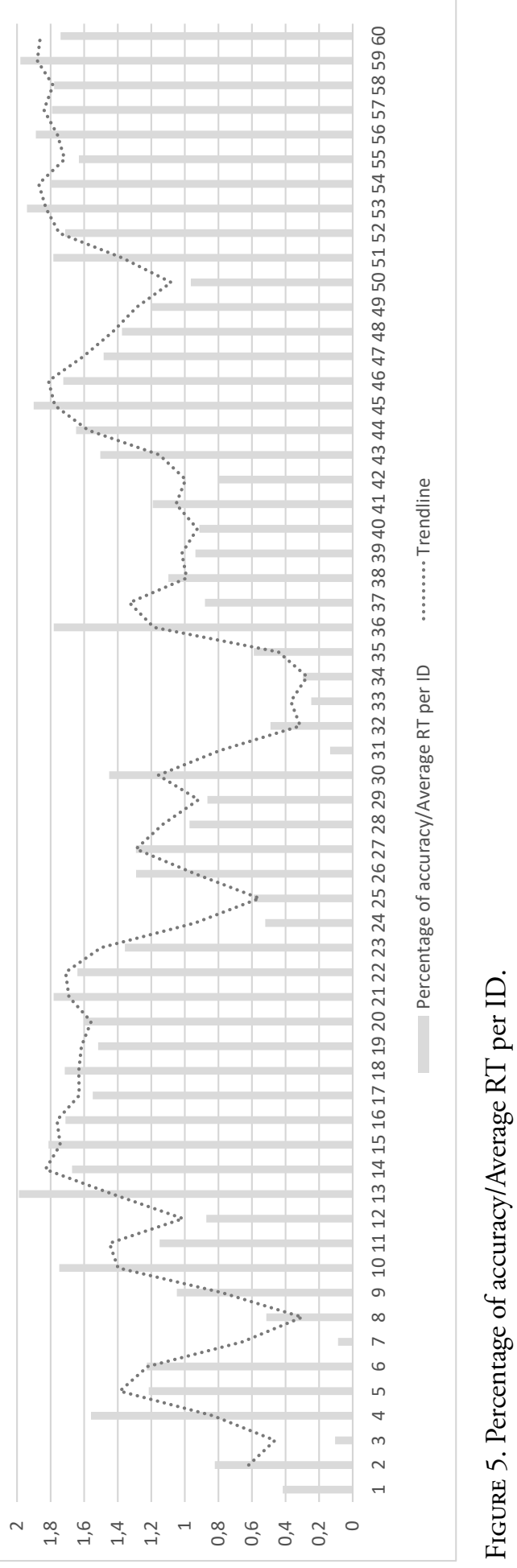


were only answered correctly by two out of 33 participants, which is merely $6 \%-$ both entail the same two phonemes, / $\theta /$ and /f/, only played in a different order. The accuracy for the 16 non-differing IDs ranged from 94 to 100\%, averaging at $99 \%$.

The average RT by all participants per ID is presented in Figure 4. The horizontal line signifies the total average RT by all participants for all IDs. For differing IDs, the minimal average RT per ID was $526.15 \mathrm{~ms}$, and the maximum $883.85 \mathrm{~ms}$. The average RT of non-differing IDs ranged from 499.67 to $626.27 \mathrm{~ms}$, averaging at $557.24 \mathrm{~ms}$. The total average RT was $665.74 \mathrm{~ms}$.

Figure 5 presents the percentage of accurate discriminations per ID, divided by the average RT per ID. After taking into account the time component, the IDs grouped closely in Figure 3 are now farther apart. In differing IDs, the highest success coefficient was achieved for IDs 45, 21 and 36. The lowest success coefficient was achieved for IDs 7, 3 and 31 .

Figures 3 and 5 show a great similarity with regard to trendline shapes.

Each ID was categorised into one of the four correlation patterns. The most numerous group of IDs follows Pattern I, and the least numerous falls into Pattern IV, see Table 6.

TABLE 6. Classification of IDs within correlation patterns.

\begin{tabular}{|l|l|c|}
\hline Pattern & ID & Sum \\
\hline I & $\begin{array}{l}4,10,13,14,15,16,17,18,19,20,21,22,27,36,43,44,45, \\
46,51,52,53,54,55,56,57,58,59,60\end{array}$ & 28 \\
\hline II & $5,6,9,11,23,26,30,38,47,48,49,50$ & 12 \\
\hline III & $1,2,7,8,12,25,28,29,31,32,34,35,37,39,40,42$ & 16 \\
\hline IV & $3,24,33,41$ & 4 \\
\hline
\end{tabular}

In the next step the phonological categories were considered. Table 7 links the IDs to their phonological categories. The number (ACC. [\#]) and the percentage (ACC. [\%]) of correct discriminations and the average RT per phonological category are presented.

TABLE 7. Accuracy and RT per phonological category.

\begin{tabular}{|l|l|c|c|c|c|}
\hline CAT. & LABEL & ID & ACC. [\#] & ACC. [\%] & RT [ms] \\
\hline 1 & DRESS vS. TRAP & $19-22$ & 32.75 & 99.24 & 608.82 \\
\hline 2 & DRESS vs. SQUARE & $23-26$ & 22.00 & 66.67 & 707.49 \\
\hline 3 & TRAP VS. SQUARE & $27-30$ & 26.75 & 81.06 & 720.86 \\
\hline 4 & DRESS vS. DEBLO & $31-34$ & 7.00 & 21.21 & 712.48 \\
\hline 5 & TRAP VS. DEBLO & $35-38$ & 25.00 & 75.76 & 734.05 \\
\hline 6 & SQUARE VS. DEBLO & $39-42$ & 22.75 & 68.94 & 724.27 \\
\hline 7 & DRESS VS. LES & $43-46$ & 32.50 & 98.48 & 584.35 \\
\hline
\end{tabular}




\begin{tabular}{|l|l|c|c|c|c|}
\hline 8 & KIT vs. LES & $47-50$ & 29.75 & 90.15 & 728.42 \\
\hline 9 & $\begin{array}{l}\text { Place of } \\
\text { articulation }\end{array}$ & $1-10$ & 20.80 & 63.03 & 737.40 \\
\hline 10 & Voicing & $11-12$ & 26.00 & 78.79 & 785.73 \\
\hline 11 & Control & $\begin{array}{c}13-18, \\
51-60\end{array}$ & 32.64 & 98.89 & 557.24 \\
\hline
\end{tabular}

The highest accuracy rate (99.24\%) was achieved in Category 1, while Category 4 reached a notably low accuracy of $21.21 \%$. Excluding the control category, the best average RT was recorded for Category 7; the worst was recorded for Category 10.

To evaluate the relationship between accuracy and RT, we again cross-referenced the phonological categories with the correlation patterns. This is presented in Table 8 .

TABLE 8. Cross-reference of phonological categories and correlation patterns.

\begin{tabular}{|l|l|r|r|r|r|}
\hline CAT. & LABEL & \multicolumn{1}{|c|}{ Pattern I } & Pattern II & Pattern III & $\begin{array}{c}\text { Pattern } \\
\text { IV }\end{array}$ \\
\hline 1 & DRESS vs. TRAP & $19,20,21,22$ & & & \\
\hline 2 & DRESS vs. SQUARE & & 23,26 & 25 & 24 \\
\hline 3 & TRAP vs. SQUARE & 27 & 30 & 28,29 & \\
\hline 4 & DRESS vs. DEBLO & & & $31,32,34$ & 33 \\
\hline 5 & TRAP vs. DEBLO & 36 & 38 & 35,37 & \\
\hline 6 & SQUARE vs. DEBLO & & & $39,40,42$ & 41 \\
\hline 7 & DRESS vs. LES & $43,44,45,46$ & & & \\
\hline 8 & KIT vs. LES & & $47,48,49$, & & \\
\hline 9 & Place of articulation & 4,10 & $5,6,9$ & $1,2,7,8$ & 3 \\
\hline 10 & Voicing & & 11 & & 12 \\
\hline 11 & Control & $13-18,51-60$ & & & \\
\hline
\end{tabular}

Categories 1, 7, 8 and 11 fall into a single pattern, while others appear in several patterns.

Finally, we separated the vocalic and consonantal contrasts into phonological supercategories: vowels, consonants, and the control category. Table 9 presents the accuracy and RT per supercategory.

TABLE 9. Accuracy and RT per phonological supercategory.

\begin{tabular}{|l|r|r|}
\hline SUPERCATEGORY & \% $_{\text {COR }}$ & RT [ms] \\
\hline Vowels & 75.19 & 690.09 \\
\hline Consonants & 70.91 & 761.57 \\
\hline Control & 98.89 & 557.24 \\
\hline
\end{tabular}


Of the two tested supercategories, vowels have a higher accuracy rate and a lower average RT than consonants. The control category achieved a nearly perfect accuracy rate and an average RT well below the total average RT.

To assess the perceived difficulty, we again examined correlation patterns. Table 10 presents the distribution of supercategories across correlation patterns in percentages.

TABLE IO. Percentage of phonological supercategories in correlation patterns.

\begin{tabular}{|l|l|r|r|r|r|}
\hline CODE & LABEL & Pattern I & Pattern II & Pattern III & Pattern IV \\
\hline V & Vowels & $31 \%$ & $25 \%$ & $34 \%$ & $9 \%$ \\
\hline C & Consonants & $17 \%$ & $33 \%$ & $42 \%$ & $8 \%$ \\
\hline CC & Control & $100 \%$ & - & - & - \\
\hline
\end{tabular}

The supercategories of vowels and consonants distributed across all four patterns. For a visual representation, we created a distribution chart for the patterns associated with vowels and consonants, see Figure 6 below.

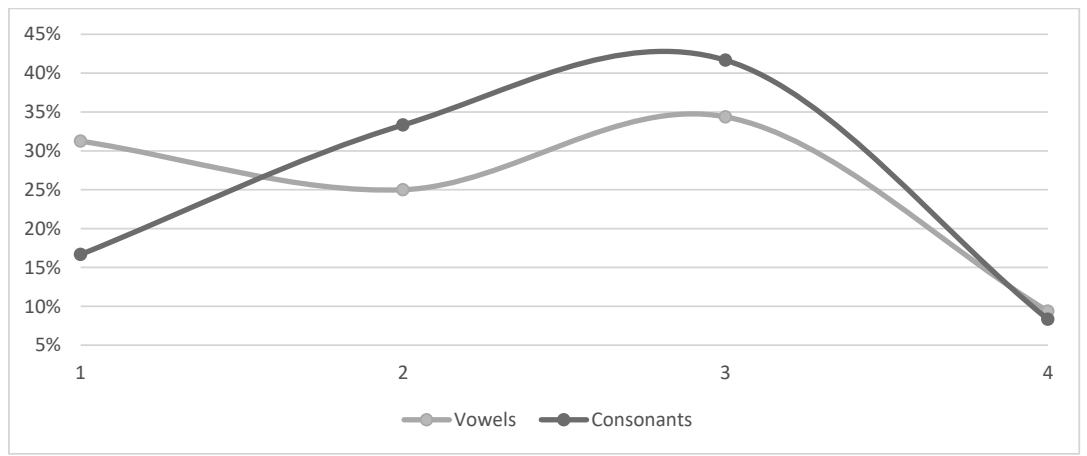

FIGURE 6. Distribution of supercategories across correlation patterns.

The vocalic line starts high in Pattern I, gently declines toward Pattern II, inclines toward Pattern III and steeply drops toward Pattern IV. On the other hand, the consonantal line starts low in Pattern I, then inclines all the way to Pattern III, and steeply drops toward Pattern IV.

\subsection{Positive Control Group}

Regarding accuracy, the results of the positive CG range from 60\% to $100 \%$ per ID, with the average of $96 \%$. The shortest RT was $402.60 \mathrm{~ms}$, the longest $1292.20 \mathrm{~ms}$, and the total average $665.04 \mathrm{~ms}$. The worst performing phonological category was Category 4 (DRESS vs. DEBLO) with an $80 \%$ success rate.

In the supercategories, vowels achieved the average accuracy of $96 \%$ with the average RT of $690.62 \mathrm{~ms}$. The accuracy rate for consonants was also 96\%, with the average RT 
of $718.68 \mathrm{~ms}$. The control category achieved $98 \%$ with the average RT of $575.90 \mathrm{~ms}$. Regarding patterns, both vowels and consonants peaked in Pattern II, with vowels starting higher in Pattern I. The control category started very high in Pattern I and steeply dropped toward Pattern III.

\subsection{Negative Control Group}

Regarding accuracy, the results of the negative CG range from $0 \%$ to $100 \%$ per ID. IDs 7 and 31 achieved $0 \%$, with below average RT times. The shortest RT was $195.80 \mathrm{~ms}$, the longest $959.20 \mathrm{~ms}$, and the total average $596.49 \mathrm{~ms}$. The worst performing phonological category was Category 4 (DRESS vs. DEBLO) with a $20 \%$ success rate. Other categories with the success rate below $65 \%$ were Categories 6 (SQUARE vs. DEBlo), 8 (KIT vs. LES), 2 (DRESS vs. SQUARE), and 9 (place of articulation). Category 7 (DRESS vs. LES) outperformed the control category (96\%) and achieved a perfect score. The pattern analysis showed the worst two categories were 4 and 6 .

In the supercategories, vowels achieved an average accuracy of $63 \%$ with the average RT of $631.29 \mathrm{~ms}$. The accuracy rate for consonants was $71 \%$, with the average RT of 637.63 ms. The control category achieved $95.67 \%$ with the average RT of 490.44 ms. Regarding patterns, vowels began low in Pattern I and peaked in Pattern III. Consonants began higher in Pattern I, peaked in Pattern II and then dropped steeply. ID 13 from the control category fell into Pattern IV.

\section{Discussion}

The findings on accuracy rates and the response times provide useful information on the perception of phoneme contrasts. We believe that the data - even in their raw form - could be used to plan and design classroom activities targeting the most problematic sounds. But before doing so, it should be considered which is more desirable, a shorter RT with a lower percentage of correct discriminations, or a longer RT with a higher percentage of correct discriminations. Or, in more general terms, which has greater weight, the accuracy of a participant's perception or their RT?

The above issue was addressed by examining the correlations between accuracy and RT. The data on accuracy and RT were combined into a single number (see Figure 5), a correlation coefficient, which indicates that accuracy should be treated as more important than RT: the accuracy rates represent the actual difficulty of the tested phonemic contrasts, while the RT data reveal the difficulty of the contrasts as perceived by the participants. The two types of results were combined into four patterns, which are listed below from most to least desirable.

Pattern I-high accuracy and short RT: The pattern marks a non-problematic contrast. The participants had little or no trouble recognising the potential difference between 
the two recordings. We assume that they successfully created a separate phonological category for the non-native phoneme (in line with Flege 1995).

Pattern II - high accuracy and long RT: The pattern points to some difficulty in discrimination. More time was needed to process the difference, but the participants mostly identified it correctly. This pattern could be linked to their training in phonetics, which tends to emphasise problematic FL phoneme contrasts. For the IDs in this group, it can be assumed that the participants were in the process of creating a phonological category.

Pattern III - low accuracy and long RT: The pattern is characteristic of difficult contrasts. The participants were not confident in their answers and made incorrect decisions. We assume that a separate phonological category was not created for the non-native phoneme; however, some awareness of a difference between the recorded stimuli existed.

Pattern IV - low accuracy and short RT: The pattern includes the most challenging pairs of stimuli. The short RT reveals that the participants were confident in their decision (fast responses), but this decision was ultimately incorrect. A separate phonological category for the non-native phoneme was not created; the participants were not aware of the misperception.

\subsection{Phonological Categories: Vowels}

The above patterns become a valuable source of information when cross-referenced with the studied phonological categories (cf. Tables 7 and 8). Categories 1-8 focused on the perception of $\mathrm{GB} / \mathrm{StS}$ vowels. The following categories were addressed.

DRESS vs. TRAP (Category 1) - Pattern I: The contrast was perceived accurately and with a fast RT. A factor contributing to the successful discrimination may be explicit instruction (in the sense of Saito 2012) combined with the number of years spent in the Department of English. The two phonemes have been previously discussed in both perception and production studies (Šuštaršič 2005; Stopar 2015; 2019; Komar 2017). Stopar's $(2015 ; 2019)$ results indicate comparatively low perception rates $(70 \%$ correct for DRESS and $75 \%$ correct for TRAP at the end of Year 1$)$, while Komar's (2017) production study yielded a perfect score for DRESS and a poor result for TRAP (49\% correct for reading from orthography). It should be noted, though, that these studies focus on first-year students, while our participants were at the same department two to three years longer.

DRESS VS. SQUARE (Category 2) - Patterns II, III, IV: The contrast is distributed among three patterns indicating various issues with either accuracy, RT, or both. We can conclude that both the quality and quantity of the GB vowels DRESs /e/ and SQUARE $/ \varepsilon: /$ mitigate the perception; it is especially noteworthy that the results for this pair are better than those for the pair GB SQUARE / $\varepsilon$ :/ and StS DEBLo / $\varepsilon /$ (see Category 6 below). 
TRAP VS. SQUARE (Category 3) - Patterns I, II, III: This is an entirely non-native contrast with the main difference in both length and degree of openness. As mentioned by Šuštaršič (2005), a phoneme which differs from a familiar phoneme in two aspects is much more difficult to acquire than a phoneme which only differs in one aspect. While the participants performed well with the stimuli with an initial approximant /l/ (Patterns I and II), the stimuli with the initial plosive /p/ were more challenging (Pattern III).

DRESS vs. DEBLO (Category 4) - Patterns III, IV: The vowels in GB DRESS and $\mathrm{StS}$ DEBLo are close on the vowel charts, although /e/ is closer to C2 than /ع/. As mentioned above, Šuštaršič also found this contrast to be a problem for Slovene speakers of English, whose pronunciation of the GB /e/ tends to be too open. We can conclude that the participants do not create a separate phonological category in this case; they use the StS / $/$ / instead of the GB /e/.

GB Dress is located below C2, StS Deblo / $/$ / above C3, and GB trap below C3. Considering the three, we can establish that the contrast /e/-læ/ (see Category 1 ) was successfully discriminated; the contrast $/ \varepsilon /-/ æ /$ (see Category 5 ) was noticeably less successful; and the contrast /e/-/E/ (Category 4) was least successful. The StS vowel $/ \varepsilon /$ which lies between the two GB vowels is therefore confused both with the more closed GB /e/ and with the more open GB /æ/. It can be concluded that the StS / $/ \varepsilon$ / acts as a perceptual magnet (Kuhl 1991), replacing GB /e/ and GB /æ/; such a result indicates that separate phonological categories for the non-native vowels were not created successfully.

TRAP vs. DEBlo (Category 5) - Patterns I, II, III: StS Deblo contains a more open vowel than GB DRESS (see Category 1 above), so it may be easier to confuse it with that of GB TRAP. While the DRESS-TRAP contrast receives ample attention in phonetics courses, perhaps special attention should also be paid to the native $\mathrm{St} S$ vowel $/ \varepsilon /$ in contrast to GB /æ/.

SQUARE vs. DEBLO (Category 6) - Patterns III, IV: The contrast between GB SQUARE and GB DEBLO is highly problematic. In comparison to $\mathrm{St} S / \varepsilon /$, the GB $/ \varepsilon$ :/ is slightly lower on the vowel chart, more fronted, and longer, as it originates from a diphthong. It should be noted that the participants were taught the phonological system with the SQUARE vowel pronounced as the diphthong /ea/ and were not trained to recognise the contrast, which may be a contributing factor explaining the poor results. Since many dictionaries, textbooks and other study materials still treat the SQUARE-vowel as a diphthong, such misperceptions are likely to remain an issue.

DRESS vs. LES (Category 7) - Pattern I: The contrast was perceived accurately and with a fast RT. The successful discrimination is likely be due to (positive) native language transfer: the pair is like the native contrast between $\mathrm{St} S$ deblo vs. StS les. 
KIT vs. LeS (Category 8) - Pattern II: The contrast falls into Pattern II - the participants considered the potential difference between two stimuli for a longer time, but ultimately made the correct decision. It has been reported in the literature that this contrast is not very obvious - Šuštaršič $(2005,12)$ describes GB /I/ as

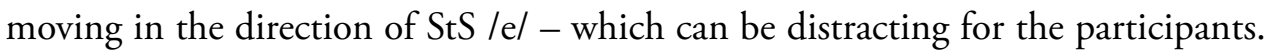
The formation of a separate phonological category for $\mathrm{GB} / \mathrm{I} /$ is thus somewhat hindered by StS /e/.

\subsection{Phonological Categories: Consonants}

The categories targeting the place of articulation (Category 9) and voicing (Category 10) are distributed among all four patterns.

Place of Articulation (Category 9) - Patterns I, II, III, IV: The contrast $/ \mathrm{t} /-/ \theta /$ (and $/ \theta /-/ \mathrm{t} /)$ falls into Pattern I and caused no problems. Pattern II comprises contrasts $/ \mathrm{d} /-/ \partial /$ (and $/ ð /-/ \mathrm{d} /$ ) and $/ \mathrm{r} /-/ \mathrm{x} /$, which required longer RTs but were generally discriminated correctly. In combination with plosives, the non-native dental consonants are easily discriminated.

The majority of the remaining contrasts $(/ \mathrm{I} /-/ \mathrm{f} /, / \mathrm{f} /-/ \theta /$, and $/ \mathrm{h} /-/ \mathrm{x} /)$, however, matched Pattern III. According to the information and advice provided in Collins, Šuštaršič and Komar (2014, 27), "[p]roblems with /h/ are very common and persistent with Slovene learners of English and careful training is required". As for contrasts $/ \mathrm{f} /-/ \mathrm{x} /$ and $/ \mathrm{f} /-/ \theta /$ (and $/ \theta /-/ \mathrm{f} /$ ), it was observed that the contrasts with the native stimulus in the first position were more successfully perceived than those with the non-native stimulus in the first position. The nature of the problem may be psychological and is outside the scope of our study.

The contrast $/ \theta /-/ f /$ was initially not included in the experiment, as it had not been detected as a problem in the pronunciation of advanced students; however, it is known that it does appear in the speech of untrained Slovene speakers of English. The phenomenon of switching / $\theta /$ for / $/$ / is common in Cockney (Cruttenden 2014, 90) and other regional dialects, pointing to a great resemblance between the phonemes that even native speakers detect and rely on. The poor results for this pair (Pattern IV) may be caused by the noise component in both phonemes (see Cruttenden, 2014). This component is not present in $/ t /$, which was successfully contrasted with $/ \theta /$. The results of the control category of IDs also show that the difference between the recordings (or its absence) was clear: the participants were able to correctly determine that the repeated recordings for $/ \mathrm{f} /$ and $/ \theta /$ were identical. Nevertheless, due to the emphasis on the pronunciation of $/ \theta /$ in phonetics (and general FL) courses, it is unlikely that the observed perception problem would permeate into production in advanced students of English. 
Voicing (Category 10) - Patterns II, III: This category includes two contrasts, / $/$ /-/ð/ and $/ \mathrm{t} /-/ \mathrm{d} /$. The non-native contrast $/ \theta /-/ \partial /$ was discriminated accurately, but after a longer consideration, thereby falling into Pattern II. In contrast, the native contrast $/ \mathrm{t} /-/ \mathrm{d} /$ falls into Pattern III: the results show long RTs and inaccurate discrimination. This is unexpected because the same contrast also appeared in the preliminary phase of the experiment, where it was always discriminated correctly. Any phonological factors can thus be excluded, as well as any potential issues with the average duration of the experiment (about 3.5 minutes). The finding should be examined further in subsequent studies.

\subsection{Vowels and Consonants Compared}

The examination of the supercategories shows that the control category had the shortest average RT and the highest accuracy rate, while the results for the supercategories of vowels and consonants confirm our hypothesis: vowels had a higher accuracy rate and a shorter average RT.

The four patterns were also used to examine the performance of the supercategories in more detail (see Table 10 and Figure 6). The consonant supercategory exhibits a poor result in the most desirable Pattern I, whereas the same pattern can be identified for almost a third of the stimuli in the vowel category. The same can be observed for Patterns II and III - the total number of consonants following these patterns is greater than that for vowels. Pattern IV is relatively rare for both groups.

The results of the control groups are as expected. The positive CG performed very well, with negligible differences in success rates of vowel or consonant discrimination. The few incorrect responses were spread across different IDs, which indicates that it was possible to discriminate all IDs correctly.

The results of the negative CG show that the average RTs per ID were much shorter than in the focus group. This may be attributed to psychological factors, e.g., the subjects being unburdened by their results and performance. The negative CG had many problems with vocalic contrasts, achieving an average success rate of only $63 \%$. The most problematic phonological categories contrasted / $\varepsilon /$ with /e/ or $/ \varepsilon: /$. Additionally, the responses in these categories were quick, showing that the subjects believed their responses to be accurate. Another notable problem was the contrast/e/-/I/. Categories including /æa/ were less problematic; the subjects may have interpreted it as /a/. Their performance was better with consonants, and near perfect with control IDs. As we predicted, the vocalic contrasts are more difficult for inexperienced speakers. The analyses of supercategories and patterns show that these subjects were generally better and faster at discriminating consonants than vowels, which suggests that their initial ability to discriminate vowels is worse than that of consonants. If this is compared to the results of the focus group, we can conclude that the same ability progresses more 
rapidly and reaches a higher level in advanced students. This signifies that students tend to prioritise vowels in the acquisition of non-native phonemes.

Although the general results confirm our hypothesis on the prioritisation of vowels, the strongest perceptual magnet pull was observed in $\mathrm{StS} / \varepsilon /$ in relation to $\mathrm{GB}$ /e, $\varepsilon:$ : æ/. This is unsurprising as several researchers have identified these phonemes as problematic (see Šuštaršič 2005; Stopar 2015). This can be interpreted as a consequence of the similarity between the four phonemes. Most likely, many students did not create separate phonological categories for the different similar phonemes; rather, they extended their original native category to encompass the similar foreign sounds. The participants who achieved higher discrimination rates in these categories, on the other hand, can be assumed to have successfully established a new category for each of these foreign phonemes.

Although the correlation between perception and production is not perfect, we can assume that the phonemes which were discriminated correctly (Patterns I and II) most likely do not cause problems in production. The incorrectly discriminated phonemes (Patterns III and IV), however, are likely to be problematic in production, as has been suggested and established in some of the literature in this field (see Stopar 2015, 87; Komar 2017).

Even with the strong influence of the StS perceptual magnet / $/ \varepsilon$ lowering the general success rate for vowels, the results show that students acquire the ability to discriminate vowels at a better rate: the vowels have a significant advantage of five percentage points over consonants. The results of the negative and positive control groups support this finding. Our hypothesis that students prioritise vowels over consonants is therefore confirmed.

\section{Conclusion}

The purpose of this study was to assess the state of foreign phoneme acquisition in native Slovene students of English at the end of their undergraduate studies and to determine whether vowels are prioritised over consonants in the process of foreign language learning. These aims were approached experimentally.

The obtained results show that while the students of English who participated in the experiment have reached a high level of acquisition, there are still some common problem areas. The perceptual magnet effect is most evident in $\mathrm{StS} / \varepsilon /$ in relation to GB /e, $\varepsilon$ :, æ/, with several other phonemes also showing signs of this phenomenon. In answer to our research question, we have confirmed that, on average, students do perform significantly better in perceiving a difference between similar vocalic phonemes, even though the vocalic supercategory included a strong perceptual magnet effect. This can be interpreted as students prioritising vowels over consonants in the process of FL acquisition. 
It should be noted that the study has some limitations. While the size of the focus group is comparable to widely recognised studies, it was difficult to find suitable participants for the control groups. Even with this size limitation, the results show internal consistency and are reliable. We also believe that the number of contrasts in some categories should be increased in any future studies, especially in the category targeting voicing. The experiment could be expanded to involve focus groups of participants at different stages of the language learning process (beginner, intermediate, advanced), and to also consider the subjects' aptitude for languages or psychological factors affecting perception.

\section{References}

Abramson, Arthur S., and Leigh Lisker. 1970. "Discriminability along the Voicing Continuum: Cross Language Tests." In Proceedings of the VIth International Congress of Phonetic Sciences, Prague, 569-73. Prague: Academia.

Best, Catherine T. 1995. “A Direct Realist View of Cross-Language Speech Perception.” In Speech Perception and Linguistic Experience: Theoretical and Methodological Issues, edited by Winifred Strange, 171-203. Baltimore: York Press.

Bohn, Ocke-Schwen. 1995. "Cross-Language Speech Perception in Adults: First Language Transfer Doesn't Tell It All.” In Speech Perception and Linguistic Experience: Issues in Cross-Language Research, edited by Winifred Strange, 278-300. Timonium, MD: York Press.

Carlson, Rolf, Gunnar Fant, and Björn Gränstrom. 1970. "Some Studies Concerning Perception of Isolated Vowels." Speech Transmission Laboratory Quarterly Progress and Status Report 11 (2-3): 19-35.

—. 1975. "Two-Formant Models, Pitch and Vowel Perception." Auditory Analysis and Perception of Speech: 55-82. https://doi.org/10.1016/B978-0-12-248550-3.50008-8.

Collins, Beverly, Rastislav Šuštaršič, and Smiljana Komar. 2014. Present-Day English Pronunciation: A Guide for Slovene Students. Revised and Enlarged 2nd Edition. Ljubljana: Znanstvena založba Filozofske fakultete, Oddelek za anglistiko in amerikanistiko.

Cruttenden, Alan. 2014. Gimson's Pronunciation of English. 8th Edition. Abingdon: Routledge. Ellis, Rod. 2015. Understanding Second Language Acquisition. Oxford: Oxford University Press.

Escudero, Paola. 2002. "The Perception of English Vowel Contrasts: Acoustic Cue Reliance in the Development of New Contrasts." In New Sounds 2000: Proceedings of the Fourth International Symposium on the Acquisition of Second-Language Speech, Klagenfurt, edited by Allan James and Jonathan Leather, 122-31. Klagenfurt: University of Klagenfurt.

—. 2009. "Linguistic Perception of 'Similar' L2 Sounds." In Phonology in Perception, edited by Paul Boersma and Silke Hamann, 152-90. Berlin: Mouton de Gruyter.

Flege, James E. 1988. “The Production and Perception of Foreign Language Speech Sounds.” In Human Communication and Its Disorders, A Review, edited by Harris Winitz, 224-401. Norwood, NJ: Ablex.

—. 1992a. "Speech Learning in a Second Language." In Phonological Development: Models, Research, and Application, edited by Charles A. Ferguson, Lise Menn, and Carol Stoel-Gammon, 565-604. Timonium, MD: York Press,

—. 1992b. "The Intelligibility of English Vowels Spoken by British and Dutch Talkers." In Intelligibility in Speech Disorders: Theory, Measurement, and Management, edited by Raymond D. Kent, 157-232. Amsterdam: John Benjamins.

—. 1995. "Second Language Speech Learning: Theory, Findings and Problems." In Speech Perception and Linguistic Experience: Issues in Cross-Language Research, edited by Winifred Strange, 233-277. Timonium, MD: York Press.

Jošt, Saša. 2018. "Perception of Foreign Phonemes: Assessment and Comparison of Slovene Students of English and Russian." MA thesis, University of Ljubljana. 
Jurančič Petek, Klementina. 2014. “The 'Magnet Effect' - A Powerful Source of L1 Dialect Interference in the Pronunciation.” ELOPE 11 (1): 45-64. https://doi.org/10.4312/elope.11.1.45-64.

Kewley-Port, Diane, T. Zachary Burkle, and Jae Hee Lee. 2007. "Contribution of Consonant versus Vowel Information to Sentence Intelligibility for Young Normal-Hearing and Elderly HearingImpaired Listeners." Journal of the Acoustical Society of America 122 (4): 2365-75. https://doi. org/10.1121/1.2773986.

Komar, Smiljana. 2017. "The Relationship between the Perception and Production of Four General British Vowels by Slovene University Students of English.” Linguistica 57 (1): 161-70. https://doi. org/10.4312/linguistica.57.1.161-170.

Kuhl, Patricia K. 1991. "Human Adults and Human Infants Show a »Perceptual Magnet Effect» for Prototypes of Speech Categories, Monkeys Do Not." Perception \& Psychophysics 50 (2): 93-107. https://doi.org/10.3758/BF03212211.

Lindblom, Björn E., and Michael Studdert-Kennedy. 1967. "On the Role of Formant Transitions in Vowel Recognition." Journal of the Acoustical Society of America 42: 830-43.

Rochet, B. L. 1995. "Perception and Production of Second-Language Speech Sounds by Adults." In Speech Perception and Linguistic Experience: Issues in Cross-Language Research, edited by Winifred Strange, 379-410. Baltimore: York Press.

Saito, Kazuya. 2012. "Effects of Instruction on L2 Pronunciation Development: A Synthesis of 15 QuasiExperimental Intervention Studies.” TESOL Quarterly 46: 842-54. https://doi.org/10.1002/tesq.67.

Saito, Kazuya, and Roy Lyster. 2012.”Effects of Form-Focused Instruction and Corrective Feedback on L2 Pronunciation Development of /r/ by Japanese Learners of English." Language Learning 62: 595-633. https://doi.org/10.1111/j.1467-9922.2011.00639.x.

Stevens, Kenneth N., Alvin Liberman, Sven E. G. Öhman, and Michael Studdert-Kennedy. 1969. "Crosslanguage Study of Vowel Perception." Language and Speech 12 (1): 1-23. https://doi. org/10.1177/002383096901200101.

Stopar, Andrej. 2015. "Perception of Four General British Vowels by Slovenian University Students of English as a Foreign Language." In PTLC2015: Proceedings of the Phonetics Teaching and Learning Conference, London, 5-7 August 2015, 87-90. London: Phonetics Teaching and Learning Conference.

—. 2017. "Perception of the GB Vowels [...] by Slovenian Speakers of English. In PTLC2017: Proceedings of the Phonetics Teaching and Learning Conference UCL, London, 9-11 August 2017, 104-9. London: Phonetics Teaching and Learning Conference.

—. 2019 [forthcoming]. "Perception of General British Monophthongs: The Case of Slovene Students of English as a Foreign Language.” Jezikoslovlje.

Šuštaršič, Rastislav. 2005. English-Slovene Contrastive Phonetic and Phonemic Analysis and Its Application in Teaching English Phonetics and Phonology. Ljubljana: Znanstveni inštitut Filozofske fakultete.

Šuštaršič, Rastislav, Smiljana Komar, and Bojan Petek. 1999. “Slovene.” In Handbook of the International Phonetic Association, A Guide to the Use of the International Phonetic Alphabet, 135-139. Cambridge: Cambridge University Press.

Tatham, Mark, and Katherine Morton. 2011. A Guide to Speech Production and Perception. Edinburgh: Edinburgh University Press.

Tivadar, Hotimir. 2004. "Fonetično-fonološke lastnosti samoglasnikov v sodobnem knjižnem jeziku." Slavistična revija 52 (1), 31-48.

Toporišič, Jože. 2000. Slovenska slovnica. Maribor: Obzorja.

Veenker, Theo J. G. 2013. “The Zep Experiment Control Application (Version 1.6.3).” Utrecht: Utrecht Institute of Linguistics OTS, Utrecht University.

Watkins, Kate E., Antonio P. Strafella, and Tomas Paus. 2003. "Seeing and Hearing Speech Excites the Motor System Involved in Speech Production.” Neuropsychologia 41 (8): 989-94.

Wells, John C. 1982. Accents of English. Cambridge: Cambridge University Press.

—. 2008. Longman Pronunciation Dictionary. 3rd Edition. Harlow: Pearson Education Limited. 


\section{Appendix I: List of IDs}

\begin{tabular}{|c|c|c|c|c|}
\hline ID & $\begin{array}{l}\text { Phon. } \\
\text { cat. A }\end{array}$ & $\begin{array}{l}\text { Phon. } \\
\text { cat. X }\end{array}$ & \begin{tabular}{c|} 
Phonemic \\
transcrip. A
\end{tabular} & $\begin{array}{c}\text { Phonemic } \\
\text { transcrip. X }\end{array}$ \\
\hline 1 & S7 & S9 & /hav/ & /xav/ \\
\hline 2 & $S 8$ & $S 10$ & /.tav/ & / rav/ \\
\hline 3 & S7 & S9 & $/ \theta \mathrm{av} /$ & $/ \mathrm{fav} /$ \\
\hline 4 & S7 & S9 & $/ \theta \mathrm{av} /$ & $/$ tav/ \\
\hline 5 & S8 & $S 10$ & /ðаひ/ & $/ \mathrm{dav} /$ \\
\hline 6 & S10 & S8 & $/ \mathrm{dav} /$ & /ðаひ/ \\
\hline 7 & S9 & S7 & $/ \mathrm{fav} /$ & $/ \theta \mathrm{av} /$ \\
\hline 8 & S9 & S7 & $/ \mathrm{xa \sigma} /$ & /hav/ \\
\hline 9 & $S 10$ & S8 & /rav/ & /.tav/ \\
\hline 10 & S9 & S7 & $/ \operatorname{tav} /$ & $/ \theta \mathrm{av} /$ \\
\hline 11 & S8 & S7 & /ðaひ/ & $/ \theta \mathrm{av} /$ \\
\hline 12 & S9 & $S 10$ & $/ \operatorname{tav} /$ & $/ \mathrm{dav} /$ \\
\hline 13 & S9 & S9 & $/ \mathrm{fav} /$ & $/ \mathrm{fav} /$ \\
\hline 14 & S10 & $\mathrm{S} 10$ & /rav/ & /rav/ \\
\hline 15 & S9 & S9 & $/ \mathrm{xav} /$ & $/ \mathrm{xav} /$ \\
\hline 16 & S7 & S7 & $/ \theta \mathrm{av} /$ & $/ \theta \mathrm{av} /$ \\
\hline 17 & S8 & S8 & /ðaひ/ & /ðаひ/ \\
\hline 18 & S7 & S7 & /hav/ & /hav/ \\
\hline 19 & S1 & S2 & /pet/ & /pæt/ \\
\hline 20 & S1 & S2 & $/ \mathrm{fet} /$ & /fæt/ \\
\hline 21 & S2 & S1 & /pæt/ & /pet/ \\
\hline 22 & $\mathrm{~S} 2$ & S1 & /pæt/ & $/ \mathrm{fet} /$ \\
\hline 23 & S1 & S3 & /det/ & $/ \mathrm{d} \varepsilon: \mathrm{t} /$ \\
\hline 24 & S1 & S3 & /let/ & $/ 1 \varepsilon: \mathrm{t} /$ \\
\hline 25 & S3 & S1 & /le:t/ & /let/ \\
\hline 26 & S3 & S1 & $/ \mathrm{f} \varepsilon: \mathrm{t} /$ & $/ \mathrm{fet} /$ \\
\hline 27 & S2 & S3 & /læt/ & $/ 1 \varepsilon: \mathrm{t} /$ \\
\hline 28 & S2 & S3 & /pæt/ & $/ \mathrm{p} \varepsilon: \mathrm{t} /$ \\
\hline 29 & S3 & S2 & /pe:t/ & /pæt/ \\
\hline 30 & S3 & S2 & $/ 1 \varepsilon: t /$ & /læt/ \\
\hline 31 & $S 1$ & 56 & /let/ & $/ \mathrm{lct} /$ \\
\hline 32 & S1 & S6 & /bet/ & /bet/ \\
\hline 33 & S6 & S1 & $/ l \varepsilon t /$ & /let/ \\
\hline 34 & S6 & S1 & /bet/ & /bet/ \\
\hline 35 & $\mathrm{~S} 2$ & S6 & /bæt/ & /bet/ \\
\hline 36 & S2 & S6 & /dæt/ & $/ \mathrm{d} \varepsilon \mathrm{t} /$ \\
\hline 37 & S6 & S2 & /bct/ & /bæt/ \\
\hline 38 & S6 & S2 & $/ \mathrm{f} \varepsilon \mathrm{t} /$ & /fæt/ \\
\hline 39 & S3 & S6 & /pe:t/ & $/ \mathrm{p} \varepsilon \mathrm{t} /$ \\
\hline 40 & S3 & S6 & /f $\varepsilon: t /$ & $/ \mathrm{f} \varepsilon \mathrm{t} /$ \\
\hline 41 & S6 & S3 & /pet/ & /pe:t/ \\
\hline 42 & S6 & S3 & $/ \mathrm{f} \varepsilon \mathrm{t} /$ & /f $\varepsilon: \mathrm{t} /$ \\
\hline 43 & S1 & S5 & $/ \mathrm{fet} /$ & /fét/ \\
\hline 44 & S1 & S5 & /pet/ & /pét/ \\
\hline 45 & S5 & S1 & /fét/ & $/ \mathrm{fet} /$ \\
\hline
\end{tabular}




\begin{tabular}{|c|c|c|c|c|}
\hline 46 & S5 & $S 1$ & /pét/ & $/$ pet/ \\
\hline 47 & S4 & S5 & /dit/ & /dét/ \\
\hline 48 & S4 & S5 & /fit/ & /fét/ \\
\hline \begin{tabular}{|l|}
49 \\
\end{tabular} & S5 & S4 & /dét/ & /dit/ \\
\hline 50 & S5 & S4 & /fét/ & $/ \mathrm{fIt} /$ \\
\hline 51 & S1 & S1 & $/ \mathrm{fet} /$ & $/ \mathrm{fet} /$ \\
\hline 52 & S5 & S5 & /fét/ & /fét/ \\
\hline 53 & S6 & S6 & /bet/ & $/ \mathrm{bct} /$ \\
\hline 54 & S2 & S2 & /bæt/ & /bæt/ \\
\hline 55 & S3 & S3 & $/ f_{\varepsilon: t} /$ & $/ \mathrm{f} \varepsilon: \mathrm{t} /$ \\
\hline 56 & S4 & S4 & /fit/ & $/ \mathrm{fIt} /$ \\
\hline \begin{tabular}{|l|}
57 \\
\end{tabular} & S6 & S6 & $/ \mathrm{l} \varepsilon \mathrm{t} /$ & /let/ \\
\hline 58 & S3 & S3 & $/ l_{\varepsilon: \mathrm{t}} /$ & $/ l_{\varepsilon: \mathrm{t}} /$ \\
\hline 59 & S1 & S1 & /let/ & /let/ \\
\hline 60 & S2 & S2 & /læt/ & /læt/ \\
\hline
\end{tabular}

\section{Appendix II: Accuracy and RT per ID}

\begin{tabular}{|c|c|c|c|}
\hline ID & $\mathbf{N}_{\mathrm{COR}}$ & $\%_{\mathrm{COR}}$ & RT per ID [ms] \\
\hline 1 & 12 & $36 \%$ & 872.52 \\
\hline 2 & 21 & $64 \%$ & 774.45 \\
\hline 3 & 2 & $6 \%$ & 580.21 \\
\hline 4 & 33 & $100 \%$ & 641.21 \\
\hline 5 & 31 & $94 \%$ & 772.97 \\
\hline 6 & 32 & $97 \%$ & 790.85 \\
\hline 7 & 2 & $6 \%$ & 693.67 \\
\hline 8 & 15 & $45 \%$ & 883.85 \\
\hline 9 & 28 & $85 \%$ & 809.58 \\
\hline 10 & 32 & $97 \%$ & 554.73 \\
\hline 11 & 28 & $85 \%$ & 737.85 \\
\hline 12 & 24 & $73 \%$ & 833.61 \\
\hline 13 & 33 & $100 \%$ & 502.70 \\
\hline 14 & 33 & $100 \%$ & 597.94 \\
\hline 15 & 33 & $100 \%$ & 551.61 \\
\hline 16 & 32 & $97 \%$ & 566.67 \\
\hline 17 & 32 & $97 \%$ & 626.27 \\
\hline 18 & 33 & $100 \%$ & 582.91 \\
\hline 19 & 32 & $97 \%$ & 639.18 \\
\hline 20 & 33 & $100 \%$ & 625.15 \\
\hline 21 & 33 & $100 \%$ & 561.24 \\
\hline 22 & 33 & $100 \%$ & 609.70 \\
\hline 23 & 31 & $94 \%$ & 692.09 \\
\hline 24 & 11 & $33 \%$ & 639.42 \\
\hline 25 & 15 & $45 \%$ & 770.61 \\
\hline 26 & 31 & $94 \%$ & 727.85 \\
\hline 27 & 27 & $82 \%$ & 633.36 \\
\hline 28 & 22 & $67 \%$ & 685.73 \\
\hline 29 & 25 & $76 \%$ & 875.21 \\
\hline
\end{tabular}




\begin{tabular}{|c|c|c|c|}
\hline 30 & 33 & $100 \%$ & 689.12 \\
\hline 31 & 3 & $9 \%$ & 675.91 \\
\hline 32 & 12 & $36 \%$ & 742.45 \\
\hline 33 & 5 & $15 \%$ & 613.76 \\
\hline 34 & 8 & $24 \%$ & 817.82 \\
\hline 35 & 15 & $45 \%$ & 771.73 \\
\hline 36 & 32 & $97 \%$ & 544.45 \\
\hline 37 & 23 & $70 \%$ & 792.09 \\
\hline 38 & 30 & $91 \%$ & 827.94 \\
\hline 39 & 23 & $70 \%$ & 743.55 \\
\hline 40 & 21 & $64 \%$ & 696.52 \\
\hline 41 & 26 & $79 \%$ & 661.39 \\
\hline 42 & 21 & $64 \%$ & 795.61 \\
\hline 43 & 31 & $94 \%$ & 624.79 \\
\hline 44 & 33 & $100 \%$ & 606.64 \\
\hline 45 & 33 & $100 \%$ & 526.15 \\
\hline 46 & 33 & $100 \%$ & 579.82 \\
\hline 47 & 33 & $100 \%$ & 673.79 \\
\hline 48 & 31 & $94 \%$ & 683.21 \\
\hline 49 & 28 & $85 \%$ & 707.94 \\
\hline 50 & 27 & $82 \%$ & 848.73 \\
\hline 51 & 33 & $100 \%$ & 560.70 \\
\hline 52 & 33 & $100 \%$ & 583.76 \\
\hline 53 & 32 & $97 \%$ & 499.67 \\
\hline 54 & 33 & $100 \%$ & 555.09 \\
\hline 55 & 31 & $94 \%$ & 575.94 \\
\hline 56 & 33 & $100 \%$ & 529.73 \\
\hline 57 & 33 & $100 \%$ & 558.06 \\
\hline 58 & 32 & $97 \%$ & 545.24 \\
\hline 59 & 33 & $100 \%$ & 504.97 \\
\hline 60 & 33 & $100 \%$ & 574.58 \\
\hline
\end{tabular}

Total average $\mathrm{N}_{\mathrm{COR}}: 26.07$ (of 33)

Total $\%_{\mathrm{COR}}: \quad 79 \%$

Total RT: $\quad 665.74 \mathrm{~ms}$ 